\title{
The determination of Water Quality in Balaban Lake (West Anatolia of Turkey)with Trophic State Indices
}

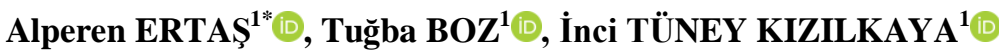 \\ ${ }^{1}$ Ege University, Faculty of Science, Department of Biology, 35100 Bornova, İzmir, TURKEY \\ *Corresponding Author: alperenertas@ hotmail.com
}

Research Article

Received 04 November 2020; Accepted 28 November 2021; Release date 01 September 2021.

How to Cite: Ertaş, A., Boz, T., \& Tüney Kızılkaya, İ. (2021). The determination of Water Quality in Balaban Lake (West Anatolia of Turkey)with Trophic State Indices. Acta Aquatica Turcica, 17(3), 350-360. https://doi.org/10.22392/actaquatr.820775

\begin{abstract}
In this study, which was carried out between October 2019- August 2020, totally five stations were chosen from the research area. Water samples (for the analysis of total phosphorus and chlorophyll- $a$ ) were taken seasonally and also Secchi disc depth and chlorophyll- $a$ were measured from these stations. Carlson's Trophic State Index, OECD criteria and value range of the Turkish Water Quality Regulation were used for the determination of the trophic status of the study area. According to obtained data, the studied area of Balaban Lake has mesotrophic character according to chlorophyll $a$, total phosphorus, and Secchi disc depth. At the end of the study, it was determined that the Balaban Lake was at the mesotrophic level according to the Carlson trophic status index, the average \pm SD interval of the OECD criteria, and Turkish Water Quality Regulation.
\end{abstract}

Keywords: Balaban Lake, Carlson Trophic State Index, OECD criteria, Turkish Surface Water Quality Regulation.

Balaban Gölü (Türkiye'nin Batı Anadolu Bölgesi) Su Kalitesinin Trofik Durum İndeksleriyle Belirlenmesi

Özet

Ekim 2019-Ağustos 2020 tarihleri arasında gerçekleştirilen bu çalışmada toplam beş istasyon seçilmiştir. Bu istasyonlardan mevsimlik peryotlarla su örnekleri alınarak toplam fosfor analizleri yapılmış, ayrıca klorofil $a$ ve seki diski derinliği ölçülmüş̧ür. Çalışma alanının trofik statüsünün belirlenmesi için Carlson Trofik Durum İndeksi, OECD kriteri ve Türkiye Yerüstü Su Kalitesi Yönetmeliği değer aralıkları kullanılmıştır. Elde edilen verilere göre, Balaban Gölü’nün çalıșlan bölgesi klorofil $a$, toplam fosfor ve seki diski derinliğine göre mezotrof karakterdedir. Çalışma sonucunda BalabanGölü’nün Carlson trofik durum indeksi, OECD ve Türkiye Yerüstü Su Kalitesi Yönetmeliği ortalama \pm 1 SD değer aralığına göre mezotrofik seviyede olduğu tespit edilmiştir.

Anahtar Kelimeler: Balaban Gölü, Carlson Trofik Durum İndeksi, OECD kriteri, Türkiye Yerüstü Su Kalitesi Yönetmeliği.

\section{INTRODUCTION}

Water, which is one of the most important resources for all organisms, is essential for the continuation of life and vitality. The increasing population in the world, the development of the industry, and the need for agricultural activities increase the importance of freshwater resources (Aksungur and Firidin, 2008). Water is an indispensable natural resource for all organisms. Although a large part of the earth is covered with water, only $3 \%$ of it is freshwater. $78 \%$ of the freshwater and $3 \%$ of usable water is found in glaciers in the north and south poles. This situation limits the required drinking and utility water ratio to $22 \%$ (Gündoğdu et al., 2007).

In terms of energy production, the thermal power plants, nuclear power plants, and river resources have remained more in the background according to the dam lakes in Turkey. With this respect, 700 dams and over 500 power plants have been built recently (Küçükyılmaz et al. 2010). To determine the effective use of a water resource, it is imperative to gather information about the resource by meticulously conducting a monitoring program that will meet the anticipated expectations (Şen and Koçer, 2003). One of the most important physicochemical factors for monitoring water quality is; to determine the factors affecting the water quality by detecting the changes in the sources of pollution and thus the pollution levels (Özbay et al., 2011). 
Eutrophication is one of the most important threats in freshwater systems, especially harmful algae blooms (HABs). Since eutrophic action can be seen in salty (ocean and marine), fresh (lake, reservoir, stream), fresh-salty (estuary, lagoon) ecosystems, developed and developing countries, it is a very common and still unresolved water quality problem. Although eutrophication reduces the quality of the water, it's commonly complained negative effects; bad image, odor, and excessive algae growth. All these problemscreate an increasing negative pressure on ecology. Therefore, many different methods of struggle are tried to combat eutrophication (Schindler et al., 2008; Schindler, 2012; Lurling and Tolman, 2014). To understand the results and effects of these methods; It is necessary to know the budgets and Spatio-temporal changes of the internal and external parameters of the ecosystem.

Izmir with its historical importance is localizing on the Mediterranean coast in the West of Turkey. Izmir is the third-largest city in Turkey. Izmir is the fastest-growing city with a 4.320 million population and an annual 9.5\% population growth rate in Western Anatolia. Balaban Lake is determined as a case area because it is an important drinking water source for İzmir. Balaban Lake is one of the important water sources of the Tahtalı Dam Lake. Lake basin which supplies $40 \%$ of city water needs. There are many industrial establishments, agricultural lands, and animal farms around Balaban Lake. Considering these factors, the pollution situation and the trophic status of Balaban Lake have not been researched yet. In this study, it is aimed to reveal the trophic situation of Balaban Lake by using Carlson's Trophic State Index, OECD criteria, and value range of the Turkish Water Quality Regulation.

\section{MATERIAL and METHODS}

\section{Study Area}

The study was carried out seasonally at five sampling points in Balaban Lake, which were determined considering the proximity to the pollutant sources and hydrodynamic properties. Spring sampling was carried in April 2020, summer sampling in August 2020, autumn sampling in October 2019, and winter sampling in January 2020. Sampling points, coordinates, and average depths are also given in Table 1 and Figure 1. 


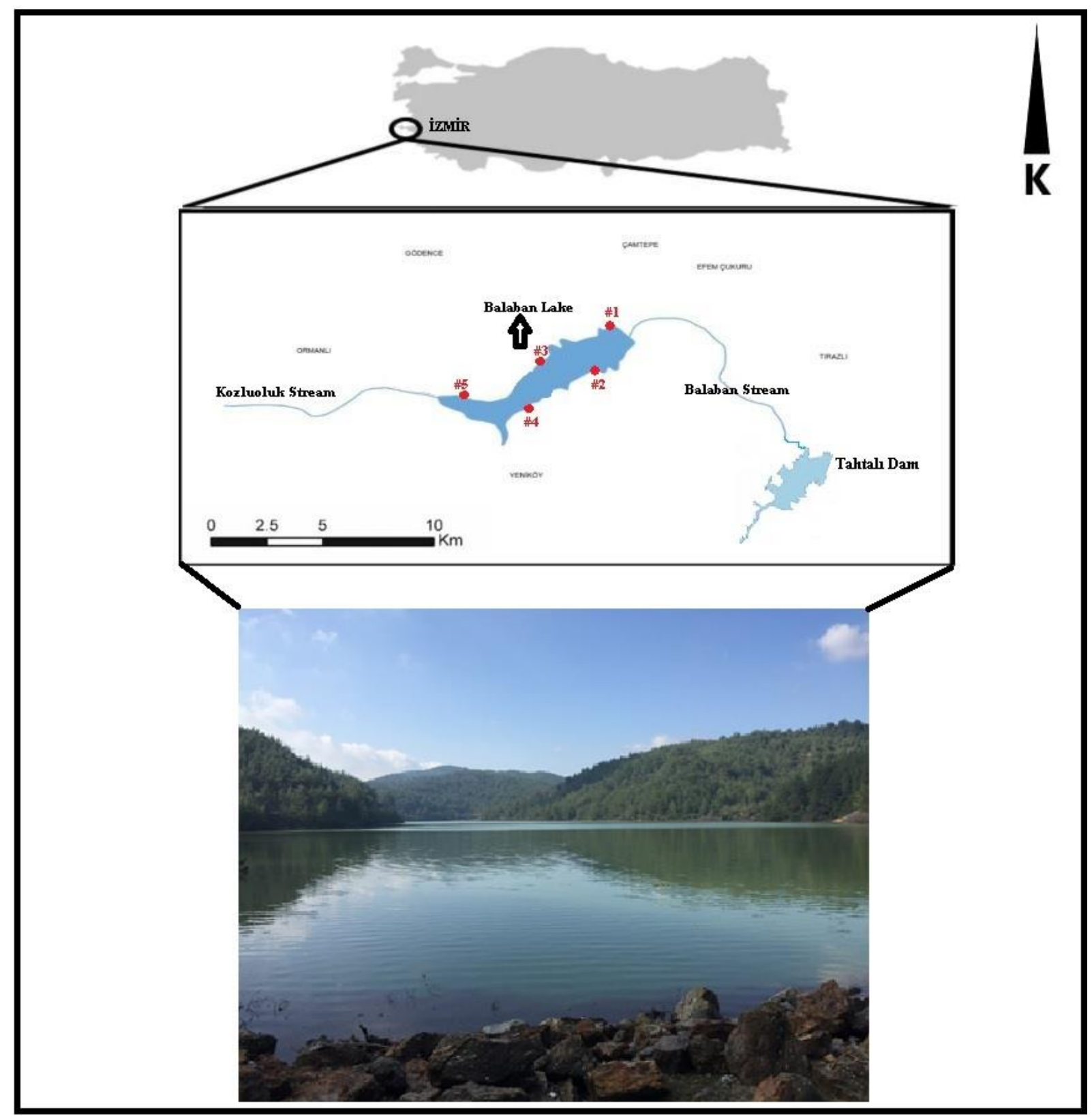

Figure 1. Study Area

Table 1. Balaban Lake sampling points, coordinates, and average depths.

\begin{tabular}{ccc}
\hline \hline Stations & Coordinates & Average depths \\
\hline Station 1 & $38^{\circ} 23^{\prime} 19.17^{\prime \prime} \mathrm{N}-27^{\circ} 02^{\prime} 68.31^{\prime \prime} \mathrm{E}$ & $6.2 \mathrm{~m}$ \\
Station 2 & $38^{\circ} 22^{\prime} 98.69^{\prime \prime} \mathrm{N}-27^{\circ} 02^{\prime} 78.50^{\prime \prime} \mathrm{E}$ & $3.3 \mathrm{~m}$ \\
Station 3 & $38^{\circ} 22^{\prime} 94.14^{\prime}{ }^{\prime} \mathrm{N}-27^{\circ} 02^{\prime} 25.07^{\prime} \mathrm{E}$ & $3.0 \mathrm{~m}$ \\
Station 4 & $38^{\circ} 22^{\prime} 68.85^{\prime}{ }^{\circ} \mathrm{N}-27^{\circ} 02^{\prime} 23.68^{\prime \prime} \mathrm{E}$ & $6.5 \mathrm{~m}$ \\
Station 5 & $38^{\circ} 22^{\prime} 69.70^{\prime \prime} \mathrm{N}-27^{\circ} 01^{\prime} 93.42^{\prime \prime} \mathrm{E}$ & $2.8 \mathrm{~m}$ \\
\hline \hline
\end{tabular}

Domestic pressures and threats arising from the settlement areas within the scope of the Balaban Lake basin can be counted as the domestic wastewater and agricultural activities of the villages on the Kozluoluk Stream, especially in the $2^{\text {nd }}, 3^{\text {rd }}$ and $5^{\text {th }}$ stations.

\section{Trophic State Indices}

Chlorophyll- $a(\mathrm{Chl} a)$, total phosphorus (TP) and Secchi depth (SD), total nitrogen (TN), and dissolved oxygen (DO) parameters are used to determine the trophic conditions of lakes. The index variables of these parameters were associated with each other by the linear regression model. Using these variables, lake waters can be classified in terms of efficiency. For example, in the light of these 
data, the nutrient level of a lake or it's status in terms of productivity can be determined in the simplest and easiest way by the trophic status index set forth by Carlson (1977), and lakes are included in a trophic class according to direct variables or indices calculated from variables.

According to the concept of trophic state, lakes are located in a series of trophic flows (oligotrophic-mesotrophic-eutrophic-hypertrophic) that progresses continuously from one to the other. If the mean values of the Carlson trophic state index (TSI), the TSI values are close to 0 , the lake is closer to the oligotrophic level, closer to 100 it is accepted that the lake has a hyperutrophic structure (Carlson and Simpson, 1996) (Table 2).

Table 2. Carlson trophic state index and its associated parameters.

\begin{tabular}{ccccc}
\hline \hline TSI & Trophic Level & Chl $\boldsymbol{a}\left(\mathbf{m g} / \mathbf{m}^{\mathbf{3}}\right)$ & Secchi $(\mathbf{m})$ & TP $(\boldsymbol{\mu g} / \mathbf{L})$ \\
\hline$<30$ & Oligotrophic & $<0.95$ & $>8$ & $<6$ \\
$40-50$ & Mesotrophic & $2.6-7.3$ & $4-2$ & $12-24$ \\
$50-60$ & Eutrophic & $7.3-20$ & $2-1$ & $24-48$ \\
$70-80$ & Hyperutrophic & $56-155$ & $0.25-0.5$ & $96-192$ \\
\hline \hline
\end{tabular}

$\mathrm{SD}$, Chl $a$, and TP are used in the formulas for calculating the Carlson TSI. The index expressed by;

$$
\begin{aligned}
& T S I=60-14.43 \ln (S D) \\
& T S I=30.6+9.81 \ln (\text { Chl } a) \\
& T S I=4.14+14.43 \ln (T P)
\end{aligned}
$$

In the OECD criteria, TP, TN, Chl $a$ and SD values are used (OECD, 1982) (Table 3).

Table 3. The OECD classification of trophic status.

\begin{tabular}{cccc}
\hline \hline Trophic Level & TP $(\boldsymbol{\mu g} / \mathbf{L})$ & $\mathbf{C h l} \boldsymbol{a}\left(\mathbf{m g} / \mathbf{m}^{\mathbf{3}}\right)$ & SD $(\mathbf{m})$ \\
\hline Oligotrophic & 8 & 1.7 & 9.9 \\
Mesotrophic & 26.7 & 4.7 & $4-2$ \\
Eutrophic & 84.4 & 14.3 & 2.45 \\
\hline \hline
\end{tabular}

In addition to these, the DO parameter is used in the trophic state index of the Turkish Surface Water Quality Regulation (Anonymous, 2012) (Table 4).

Table 4. Lake eutrophication criteria (Anonymous, 2012)

\begin{tabular}{cccccc}
\hline Trophic Level & TP $(\boldsymbol{\mu g} / \mathbf{L})$ & $\mathbf{T N}(\boldsymbol{\mu g} / \mathbf{L})$ & $\mathbf{C h l} \boldsymbol{a}(\boldsymbol{\mu g} / \mathbf{L})$ & $\mathbf{S D}(\mathbf{m})$ & $\mathbf{D O}(\mathbf{m g} / \mathbf{L})$ \\
\hline Oligotrophic & $<10$ & $<0.35$ & $<3.5$ & $>4$ & $>7$ \\
Mesotrophic & $10-30$ & $0.35-0.65$ & $3.5-9.0$ & $4-2$ & $6-4$ \\
Eutrophic & $31-100$ & $0.651-1.20$ & $9.1-25.0$ & $1.9-1.0$ & 3 \\
Hyperutrophic & $>100$ & $>1.2$ & $>25.0$ & $<1$ & $<3$ \\
\hline \hline
\end{tabular}

In the research, $\mathrm{DO}, \mathrm{TP}, \mathrm{Chl} a, \mathrm{SD}$, and $\mathrm{TN}$ data were examined. $\mathrm{DO}$ content was measured with the Oxi 315i/ SET WTW Oxygen meter. The SD was determined directly in place with the Secchi disc. TP and TN were measured by spectrophotometric technique. chl $a$ was measured in the field by using the BBE Moldaenke AlgaeTorch.

Statistical evaluation of the dataset was made by using the PAST3 and Excel 2019 (Microsoft Office $^{\mathrm{R}}$ ). Analysis of variance (One- Way ANOVA) was applied to all data and the differences between the group means were determined according to the Tukey test and multiple comparison test, and " $p<0.05$ " was used as the significance level.

\section{RESULTS}

The comparison of Balaban Lake DO, SD, TP, Chl $a$, and TN values over the stations is given in Table 5 . 
Table 5. DO, SD, TP, TN and Chl $a$ values of stations in Balaban Lake.

\begin{tabular}{|c|c|c|c|c|c|c|}
\hline \multicolumn{2}{|c|}{ Parameters } & Station 1 & Station 2 & Station 3 & Station 4 & Station 5 \\
\hline $\mathrm{DO}(\mathrm{mg} / \mathrm{l})$ & $\begin{array}{c}\mathrm{R} \\
\mathrm{M} \pm \mathrm{Sd} .\end{array}$ & $\begin{array}{c}13.4-14.1 \\
\mathbf{1 3 . 8}^{\mathbf{a b}} \pm 0.29\end{array}$ & $\begin{array}{c}12.4-14.0 \\
\mathbf{1 3 . 4}^{\mathbf{a b}} \pm 0.71\end{array}$ & $\begin{array}{c}11.1-13.5 \\
\mathbf{1 2 . 1}^{\mathrm{a}} \pm 1.07\end{array}$ & $\begin{array}{c}12.6-13.5 \\
\mathbf{1 3 . 0}^{\mathbf{a b}} \pm 0.40\end{array}$ & $\begin{array}{c}10.8-12.4 \\
\mathbf{1 1 . 5}^{\mathbf{b}} \pm 0.73\end{array}$ \\
\hline $\mathrm{SD}(\mathrm{m})$ & $\begin{array}{c}\mathrm{R} \\
\mathrm{M} \pm \mathrm{Sd}\end{array}$ & $\begin{array}{c}4.0-5.0 \\
\mathbf{4 . 7 5}^{\mathrm{ab}} \pm 0.5\end{array}$ & $\begin{array}{c}0.5-0.8 \\
0.7^{\mathrm{a}} \pm 0.14\end{array}$ & $\begin{array}{c}0.3-0.8 \\
0.57^{\mathbf{b}} \pm 0.22\end{array}$ & $\begin{array}{c}4.0-5.0 \\
\mathbf{4 . 7 5}^{\mathbf{a b}} \pm 0.5\end{array}$ & $\begin{array}{c}0.3-0.8 \\
\mathbf{0 . 5 7} \\
\mathbf{b} \pm 0.22\end{array}$ \\
\hline $\mathrm{TP}(\mu \mathrm{g} / \mathrm{L})$ & $\begin{array}{c}\mathrm{R} \\
\mathrm{M} \pm \mathrm{Sd} .\end{array}$ & $\begin{array}{c}4.02-4.97 \\
\mathbf{4 . 4 9}^{\mathbf{b}} \pm 0.38\end{array}$ & $\begin{array}{l}8.23-10.14 \\
\mathbf{9 . 4 2}^{\mathbf{a}} \pm 0.84\end{array}$ & $\begin{array}{c}11.8-13.6 \\
\mathbf{1 2 . 6}^{\mathbf{a b}} \pm 0.76\end{array}$ & $\begin{array}{c}3.11-4.23 \\
\mathbf{3 . 8 2}^{\mathbf{b}} \pm 0.49\end{array}$ & $\begin{array}{c}10.2-12.5 \\
\mathbf{1 1 . 6}^{\mathbf{a b}} \pm 0.98\end{array}$ \\
\hline $\mathrm{TN}(\mathrm{mg} / \mathrm{L})$ & $\begin{array}{c}\mathrm{R} \\
\mathrm{M} \pm \mathrm{Sd} .\end{array}$ & $\begin{array}{l}0.558-0.665 \\
\mathbf{0 . 6 3 2}^{\mathbf{a}} \pm 0,05\end{array}$ & $\begin{array}{c}0.660-0.699 \\
\mathbf{0 , 6 8 1}^{\mathbf{a b}} \pm 0.01\end{array}$ & $\begin{array}{c}0.682-0.711 \\
\mathbf{0 . 6 9 7}^{\text {ab }} \pm 0.01\end{array}$ & $\begin{array}{l}0.550-0.591 \\
\mathbf{0 . 5 7 7}^{\mathbf{b}} \pm 0.02\end{array}$ & $\begin{array}{c}0.691-0.703 \\
\mathbf{0 . 6 9 8}^{\mathbf{a b}} \pm 0.01\end{array}$ \\
\hline $\begin{array}{l}\text { Chl- } a \\
\left(\mathrm{mg} / \mathrm{m}^{3}\right)\end{array}$ & $\begin{array}{c}\mathrm{R} \\
\mathrm{M} \pm \mathrm{Sd}\end{array}$ & $\begin{array}{c}1.67-1.94 \\
\mathbf{1 . 7 9}^{\mathbf{a b}} \pm 0.12\end{array}$ & $\begin{array}{c}5.42-5.67 \\
\mathbf{5 . 5 5}^{\mathrm{a}} \pm 0.11\end{array}$ & $\begin{array}{c}6.32-6.97 \\
\mathbf{6 . 6 5}^{\mathbf{b}} \pm 0.32\end{array}$ & $\begin{array}{c}1.78-1.99 \\
\mathbf{1 . 8 9}^{\mathbf{a b}} \pm 0.08\end{array}$ & $\begin{array}{c}5.71-6.03 \\
\mathbf{5 . 8 5}^{\mathbf{a}} \pm 0.14\end{array}$ \\
\hline
\end{tabular}

R: Range; M: Mean; Sd: Standard deviation. *Different characters on the same line indicate that the difference between stations is statistically significant $(p<0.05)$.

During the study, Balaban Lake DO content was determined to be between 10.8-14.1 mg/L and an average of $12.8 \mathrm{mg} / \mathrm{L}$. Seasonal average DO contents were determined to be $13.2 \mathrm{mg} / \mathrm{L}$ in the spring, $12.5 \mathrm{mg} / \mathrm{L}$ in the summer, $12.1 \mathrm{mg} / \mathrm{L}$ in the autumn, and $13.3 \mathrm{mg} / \mathrm{L}$ in the winter (Figure 2).

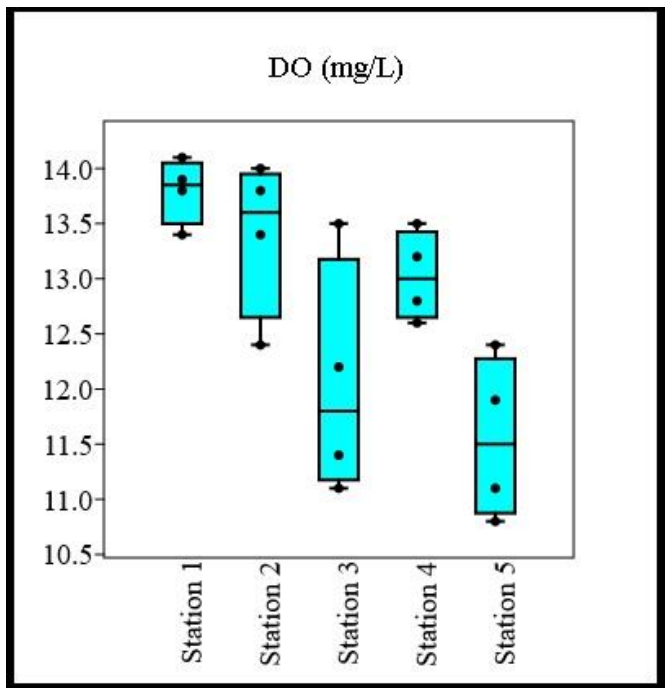

Figure 2. Balaban Lake dissolved oxygen variation graph.

SD was measured between $0.3-5.0 \mathrm{~m}$ and the average was determined to be $2.27 \mathrm{~m}$. Seasonal average SD variations are $2.42 \mathrm{~m}$ in spring, $2.36 \mathrm{~m}$ in summer, $1.82 \mathrm{~m}$ in autumn, and $2.48 \mathrm{~m}$ in winter (Figure 3).

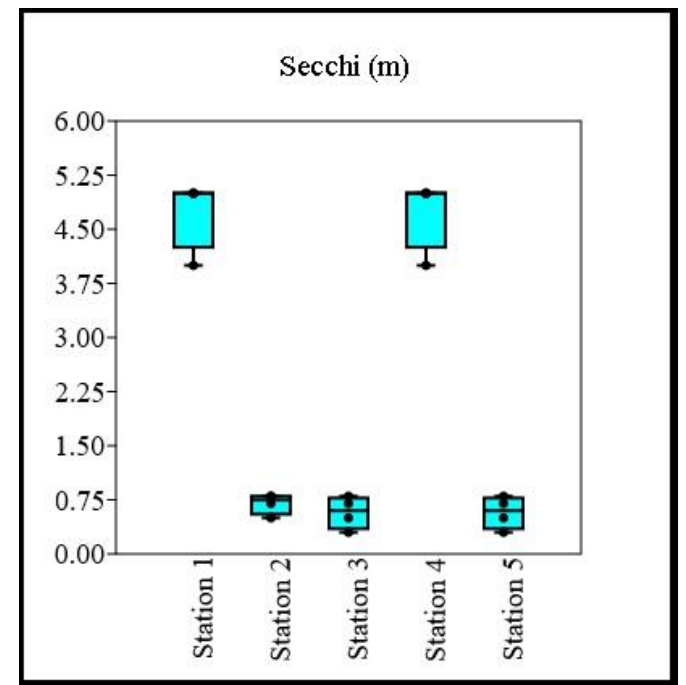

Figure 3. Balaban Lake Secchi depth variation graph. 
It was observed that the differences between stations in DO and SD parameters were statistically insignificant, but seasonal variation differences in SD were statistically significant $(p<0.05)$. The effect of wind and weather conditions at the time of measurement is evident in the inter-seasonal variability of the SD measurements.

TN values were determined between 0.55-0.71 (mean: 0.66) mg/L in Balaban Lake. The lowest TN value was determined in the $4^{\text {th }}$ station in the winter, while the highest TN value was determined in the $3^{\text {rd }}$ station in the autumn (Figure 4). In the statistical analysis, it was seen that the difference between the stations was statistically significant $(p<0.05)$.

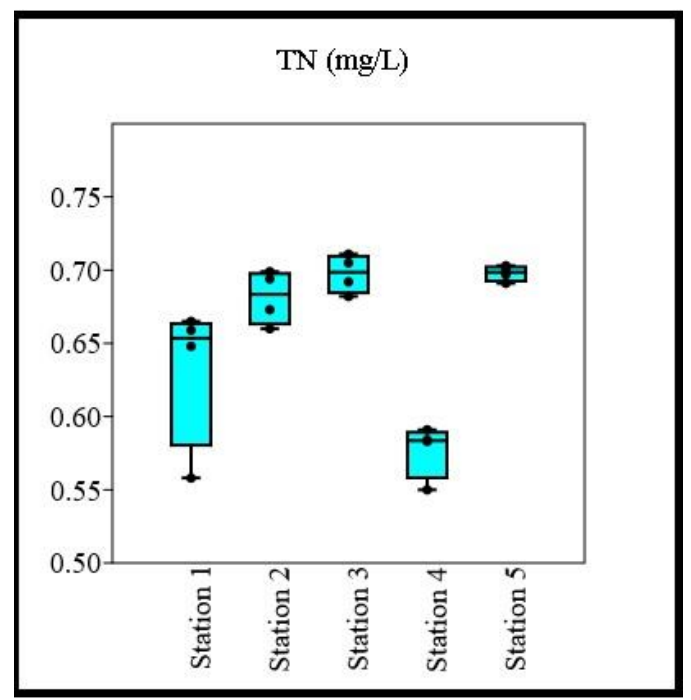

Figure 4. Balaban Lake total nitrogen variation graph.

The TP concentration of Balaban Lake varied between 3.11-12.7 (mean: 8.41) $\mu \mathrm{g} / \mathrm{L}$. In the statistical analysis, it was seen that the differences between the $3^{\text {rd }}$ and $5^{\text {th }}$ stations and all other stations were statistically significant $(p<0.05)$ (Figure 5). When seasonal TP changes were examined, average TP content was determined as $8.68 \mu \mathrm{g} / \mathrm{L}$ in spring, $8.35 \mu \mathrm{g} / \mathrm{L}$ in summer, $9.08 \mu \mathrm{g} / \mathrm{L}$ in autumn, and $7.50 \mu \mathrm{g} / \mathrm{L}$ in winter. In the $3^{\text {rd }}$ and $5^{\text {th }}$ stations, Kozluoluk Stream, which dries up especially in summer, transports pollutant loads to the lake during rainy periods. This situation causes TP values to be higher than other stations.

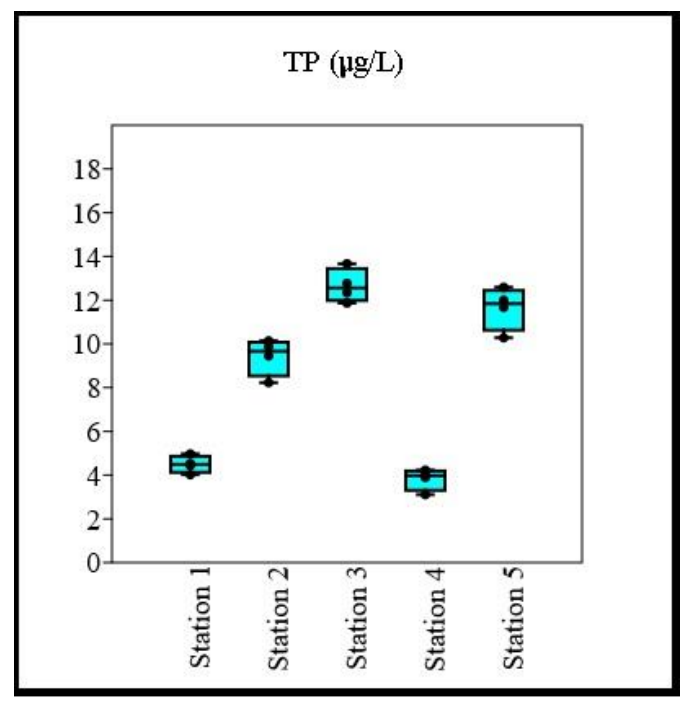

Figure 5. Balaban Lake total phosphorus variation graph.

The chl measurements of Balaban Lake varied between 1.67-6.97 (mean: 4.35) $\mu \mathrm{g} / \mathrm{L}$ (Figure 6). In the statistical analysis, it was seen that the differences between the $2^{\text {nd }}, 3^{\text {rd }}$ and $5^{\text {th }}$ stations and other two stations $\left(1^{\text {st }}\right.$ and $\left.4^{\text {th }}\right)$ were statistically significant $(p<0.05)$. The seasonal chl $a$ levels of Balaban Lake were determined to be $4.26 \mu \mathrm{g} / \mathrm{L}$ in spring, $4.45 \mu \mathrm{g} / \mathrm{L}$ in summer, $4.51 \mu \mathrm{g} / \mathrm{L}$ in autumn and 4.18 
$\mu \mathrm{g} / \mathrm{L}$ in winter. No statistically significant difference was observed between the seasons based on chl $a$ value $(p<0.05)$.

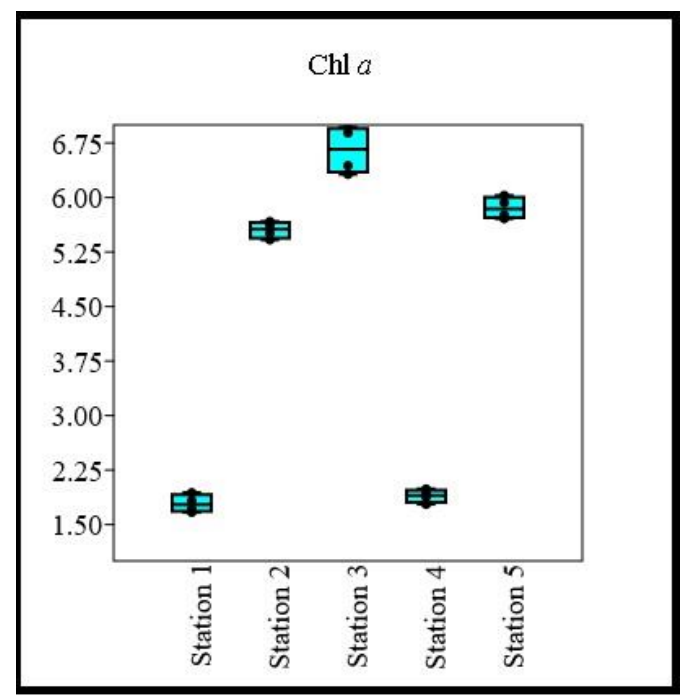

Figure 6. Balaban Lake chl $a$ variation graph.

Carlson TSI (SD) values in Balaban Lake varied between 36.6-77.5. The highest TSI (SD) value was determined in the $3^{\text {rd }}$ and $5^{\text {th }}$ stations in the autumn, and the lowest TSI (SD) value in the $1^{\text {st }}$ and $4^{\text {th }}$ stations in the autumn. The difference between stations in terms of TSI (SD) values was not found to be statistically significant $(p<0.05)$.

Carlson TSI (TP) values in Balaban Lake varied between 23.7-41.8. The lowest TSI (TP) value was calculated at the $4^{\text {th }}$ station in the summer and the highest TSI (TP) value at the $3^{\text {rd }}$ station in the autumn. The difference between stations in terms of TSI (TP) values was not found to be statistically significant $(p<0.05)$.

Carlson TSI (Chl $a$ ) values varied between 35.6-49.6 in Balaban Lake. In Balaban Lake, the highest TSI ( $\operatorname{chl} a$ ) value was recorded at the $3^{\text {rd }}$ station in the autumn, and the lowest TSI ( $\operatorname{chl} a$ ) value at the $1^{\text {st }}$ station in the winter. The difference between stations in terms of TSI (chl $a$ ) values was not found to be statistically significant $(p<0.05)$.

According to the Carlson TSI, it was determined that Balaban Lake showed mesotrophic characteristics in terms of average TSI (SD), TSI (TP) and TSI (chl $a$ ) values. Balaban Lake was at the mesotrophic level according to the average TSI values in general (Table 6).

Table 6. Carlson trophic state index results.

\begin{tabular}{ccc}
\hline \hline TSI & Average Score & Trophic Level \\
\hline TSI (Chl $a$ ) & 43.5 & Mesotrophic \\
TSI (SD) & 50.0 & Mesotrophic \\
TSI (TP) & 33.2 & Mesotrophic \\
TSI (average) & 43.2 & Mesotrophic \\
\hline \hline
\end{tabular}

According to the OECD criteria, it was determined that it has mesotrophic properties in terms of TP; it has oligotrophic properties in terms of chl $a$; it has eutrophic properties in terms of SD parameter (Table 7).

Table 7. OECD trophic state index results.

\begin{tabular}{ccc}
\hline \hline Parameters & Average Score & Trophic Level \\
\hline $\mathrm{TP}(\mu \mathrm{g} / \mathrm{L})$ & 8.4 & Mesotrophic \\
$\mathrm{TN}(\mathrm{mg} / \mathrm{L})$ & 0.65 & Oligotrophic \\
$\mathrm{Chl} a\left(\mathrm{mg} / \mathrm{m}^{3}\right)$ & 4.34 & Oligotrophic \\
$\mathrm{SD}(\mathrm{m})$ & 2.27 & Eutrophic \\
\hline \hline
\end{tabular}


According to the trophic status index of the Turkish Surface Water Quality Regulation, it was determined that it has oligotrophic in terms of DO and TP values, mesotrophic in terms of TN, SD, and chl $a$ (Table 8).

Table 8. Turkish Surface Water Quality Management Regulation trophic state index results.

\begin{tabular}{ccc}
\hline \hline Parameters & Average Score & Trophic Level \\
\hline TP $(\mu \mathrm{g} / \mathrm{L})$ & 8.4 & Oligotrophic \\
TN $(\mathrm{mg} / \mathrm{L})$ & 0.65 & Mesotrophic \\
Chl $a\left(\mathrm{mg} / \mathrm{m}^{3}\right)$ & 4.34 & Mesotrophic \\
SD $(\mathrm{m})$ & 2.27 & Mesotrophic \\
DO $(\mathrm{mg} / \mathrm{L})$ & 12.8 & Oligotrophic \\
\hline \hline
\end{tabular}

\section{DISCUSSION}

$\mathrm{SD}$, which is an indicator of the light transmittance of aquatic environments, generally varies depending on the depth of water. However, seasonal variations are also very effective on SD. According to the OECD (1982) trophic classification, lakes with a depth of 0.8-1.5 m are classified as eutrophic, lakes between 1.4-2.4 m as mesotrophic, and lakes between 3.6-5.9 m as oligotrophic (Ryding and Rast 1989). According to OECD (1982) values, the $1^{\text {st }}$ and $4^{\text {th }}$ stations in Balaban Lake are mesotrophic, but the $2^{\text {nd }}, 3^{\text {rd }}$ and $5^{\text {th }}$ stations exhibit a eutrophic structure. In Balaban Lake, the reason for the eutrophic situation is due to the low turbidity in these stations as a result of the growth of filamentous algae and aquatic plants. In this study carried out seasonally, the average SD value was found to be $2.27 \mathrm{~m}$. Erk'akan and Bayrak (1992) reported the average SD values of Eğirdir Lake was $1.95 \mathrm{~m}$. Zeybek et al., (2012) reported the average SD values of Eğirdir and Kovada Lake was $1.60 \mathrm{~m}$. Yağc1 et al., (2013) reported the average SD value of Eğirdir Lake was $1.77 \mathrm{~m}$ in the monthly study in 2016. Tanyolaç (2000) reported that many factors affect the transparency and light transmittance of water in lakes, such as plankton density, dissolved organic and inorganic substances in water, the chemical structure of the water, the angle and wavelength of light, the state of the water surface, and cloudiness.

Güneş et al., (2011) reported in their study that the TP content showed a distribution and change depending on the measurement time and points, however, the values detected were at low levels (8.41 $\mu \mathrm{g} / \mathrm{L})$. Researchers have reported that this situation shows meso-eutrophic properties for the lake and that it is necessary to control the use of domestic and animal wastes, especially fertilizers, and avoid mixing with the lake water as much as possible in order not to reach the further trophic level. In addition, the TP content determined in Balaban Lake provides the A1-K value in terms of Quality Standard, however, the phosphate element is extremely important for the lake water quality (in terms of algae production and eutrophication), especially with nitrogen, and it is important to control this parameter at its source absolutely. have reported. According to Zeybek et al., (2012), the average TP amount is below the lowest analysis limits in November, April, and June, highest $0.12 \mu \mathrm{g} / \mathrm{L}$ in July; the lowest 0.10 in October, the highest 0.72 in July on the channel between 2010 and 2011 in Eğirdir Lake Köprübaşı Region, Kovada Canal, and Kovada Lake Entrance Zone; They reported that the lowest analysis limits in Kovada Lake (February, April) was measured as $0.91 \mu \mathrm{g} / \mathrm{L}$ (July) (lowest analysis limits $<0.05 \mu \mathrm{g} / \mathrm{L}$ ).

Güler and Çobanoğlu (1997) reported that although phosphorus is present in many minerals, its amount in water is limited due to its low solubility in alkaline soils, it can pass through water, rocks, and soils, as well as artificial fertilizers and industrial wastes. Goldman and Horne (1983) reported that phosphorus accumulates in the embankments of deep lakes under oxygenated conditions, separates from bottom mud in $\mathrm{O}_{2}$-free environments, and passes into the water, thus causing ferric $\left(\mathrm{Fe}^{+3}\right)$ ion to decrease in efficiency since it binds $\mathrm{PO}_{4}^{-3}$ in oxygenated environments. In addition, they reported that $\mathrm{PO}_{4}^{-3}$ ion is captured by $\mathrm{Fe}^{+3}, \mathrm{CaCO}_{3}$, and mud (silt) in three different ways in waters and that mud (silt) is more effective in shallow lakes.

Dodds (2002) reported that nitrogen and phosphorus are the primary limiting nutrients in terms of algal production potential in aquatic ecosystems, however, phosphorus is a more limiting element in freshwater ecosystems than nitrogen. Howarth et al., (2000) reported that the limiting nutrient is nitrogen in marine ecosystems and phosphorus in freshwater ecosystems for algae and plant growth. 
Smith (1982) reported that when the TN/ TP ratio is $<10$, nitrogen, when the TN/ TP ratio is $>17$, phosphorus is the limiting nutrient, while the TN/ TP ratio between 10-17 is balanced for the freshwater ecosystem. Varol (2013) reported that according to Carlson TSI value, Batman Dam Lake is at a mesotrophic level, and according to the average TN/ TP ratio, phytoplankton development in the lake is limited by nitrogen and phosphorus together.

$\mathrm{Chl} a$, the essential photosynthetic pigment, is an indicator of algal biomass in water (HendersonSellers and Markland, 1987; Wetzel, 2001; Taş et al. 2019). The highest chl $a$ value was determined at the $3^{\text {rd }}$ station in autumn in Balaban Lake. Chl $a$ content was measured as low in winter months and higher in warm months. The results obtained are similar to the information provided by various researchers on chl measurements made in lakes and their seasonal changes (Taş, 2003; Maraşlioğlu, 2007; Cüce et al. 2020). Güneş et al., (2011) reported that they did not observe a significant difference between the mid-lake and surface stations in terms of chl $a$ concentration and that the measured chl values indicate a significant increase in biomass compared to previous years in their study, although they do not pose a risk for lake water in the current situation. In the control of this increase, macrophytes spreading on a significant part of the lake bottom are the factors, because water quality and productivity in shallow lakes; reported that the level of nutrient salt varies depending on high aquatic plants, phytoplankton status, light transmittance, and water level. Yağc1 et al., (2013) reported that the lake chl $a$ content varied between 0.58-9.70 $\mu \mathrm{g} / \mathrm{L}$ in Eğirdir Lake.

Jarosiewicz et al., (2011) determined the current trophic status of the lakes (Rybiec, Niezabyszewskie, Czarne, Chotkowskie, Obłęże, Jasień Południowy, Jasień Północny, Jeleń) located between the Pomeranian rivers Wieprza and Łupawa in the north of Poland with Carlson TSI. For this purpose, they analyzed four trophic state indexes (TSI (SD), TSI (chl $a$ ), TSI (TP), and TSI (TN)) and the relationship between them. As a result of the study, they reported that the trophic level of the aforementioned lakes were in mesotrophic and eutrophic conditions. They reported that the TSI (TP) values in the analyzed lakes were higher than the index values calculated based on other variables, however, the differences between indices for certain lakes indicated that phosphorus was a factor limiting algal productivity in the analyzed lakes.

Akyüz (2016) stated that the TSI ( $\mathrm{chl} a$ ) value has the lowest value in all seasons, indicating that there is a number of nutrients that can provide more algae growth than the existing algae growth. For this reason, he reported that the key limiting parameters for the lake that are more effective than nutrients should be evaluated. In addition, the lake has excess phosphorus and turbidity without algae; this indicates that nitrogen concentration and Secchi depth are key limiting parameters; He also reported that the average TN/ TP ratio of less than 30 in the summer and autumn seasons, when algae growth is high, supports this result.

Sömek and Ustaoğlu (2016) determined that the TSI (SD) results calculated from the average SD and chl $a$ measurements in the lakes in Saklıgöl, Gökçeova Pond, Kartal Lake, and Karagöl, located in the southeast of the Aegean region, are between 47.3 and 59.3. They also reported that TSI (chl $a$ ) results varied between 38.1 and 45.5, and TSI (average) varied between 42.7 and 55.5.

Tepe et al., (2018) stated that the water column of Karkamış Dam Lake between 0-8 m was mesotrophic in terms of TP, TN, and chl $a$ index values according to the Carlson TSI, and the TP amount according to the mean \pm 1 SD interval of the OECD criteria. They reported that the trophic status of the Karkamıs Dam Lake showed a transition from the oligotrophic class to the mesotrophic class, and that phosphorus was the limiting nutrient in terms of TN/ TP ratio.

The conditions that slow down the pollution effect of Balaban Lake can be counted as feeding the lake water with groundwater, the lack of industrial facilities around the lake, the low population density around the lake, and the high DO content of the water. However, it is of great importance to take precautions in the streams that are connected to the lake, to discipline irrigation and spraying in agricultural lands, and to establish wastewater treatment units in settlements connected to the lake.

As a result, it should be one of our primary duties not to pollute our waters, which are very precious for our country and the world. We need to aim to create environments in a way and in such a way that the existing pollution can be cleaned in its cycle, without destroying the environment, protecting forests and other vegetation areas. 


\section{ACKNOWLEDGEMENT}

This research was supported by the Unit of Scientific Research Projects (BAP) at Ege University (Project no: 21348).

\section{REFERENCES}

Aksungur, N., \& Firidin, Ş. (2008). Su kaynaklarının kullanımı ve sürdürülebilirlik. Yunus Araştırma Bülteni, 8$11 \mathrm{~s}$.

Akyüz, D.E. (2012). Trofik durum indeksi ile anahtar sinırlayıcı parametrelerin değerlendirilmesi: Taihu gölü örneği. Mehmet Akif Ersoy Üniversitesi Fen Bilimleri Enstitüsü Dergisi, 7(1), 194-201.

Anonymous (2016). Turkish Surface Water Quality Regulation, Official Newspaper No. 29797, 10 August 2016, Ankara.

Carlson, R.E. (1977). A trophic state index for lakes. Limnology and Oceanography, (22), 361-369.

Carlson, R.E., \& Simpson. J. (1996). A coordinator's guide to volunteer lake monitoring methods, North American Lake Management Society, 96 pp.

Cüce, H., Kalıpcı, E., Taş, B., \& Yılmaz, M. (2020). Evaluation of the Impacts on Water Quality from Meteorological Changes Due to Differences in Altitude by GIS: A Comparison for Two Morphologically Different Lakes. The Black Sea Journal of Sciences, 10(1), 1-26.

Dodds, W. K. (2002). Freshwater Ecology: Concepts and environmental applications. San Diego, CA: Academic Press.

Erk’akan, F.G., \& Bayrak, M. (1992). Eğirdir Gölü stok tespiti. TÜBiTAK DEBÇAĞ 97/G 143 s.

Goldman, C. R., \& Horne, A. J. (1983). Limnology. McGraw-Hill Book Co., New York, 464 p.

Güler, C.., \& Cobanoğlu, Z. (1997). Pestisitler, 1. Baskı, İlköz Matbaası, Ankara, 173 s.

Gündoğdu, V., Elele, M., Akgün, G., \& Piyancı, O. (2007). Su havzalarında yönetim planlaması, 7. Ulusal Çevre Mühendisliği Kongresi Bildirisi, İzmir.

Güneş, K., Dönertaş, S.A., Metin, E., Şenduran, C., Dikerler, T., Arlı, Ö., Olgun, A., Aktaş, Ö., Aydöner, C., Özdemir, Ö., Ayaz, S., Tüfekçi, H., Tüfekçi, V., Atabay, H., Mantıkçı, A.M., İnal, Ö., Kara, E., Konya, Y., Sapmaz, K., Çelik, S., Enginsoy, G., Yakupoğlu, G., \& Çelemen, M. (2011). İçme ve kullanma suyu kaynağı olarak kullanılan Eğirdir gölü havza koruma planı ve özel hüküm belirlenmesi projesi. Proje Sonuç Raporu. Proje no:5098116. TÜBiTAK-MAM, Gebze, Kocaeli, 400 s.

Henderson-Sellers, B., \& Markland, H.R. (1987). Decaying Lakes: The origins and control of cultural eutrofication. John Wiley \& Sons, Chichester.

Jarosiewicz, A., Ficek, D., \& Zapadka, T. (2011). Eutrophication parameters and Carlson-type trophic state indices in selected Pomeranian lakes. Limnological Review, 11(1), 15-23.

Küçükyilmaz, M., Uslu, G., Birici, N., Örnekçi, N. G., Yildiz, N., \& Şeker, T. (2010). Karakaya Baraj Gölü su kalitesinin incelenmesi. "International Sustainable Water and Wastewater Management Symposium" 2628 Konya/Turkey.

Lurling, M., \& Tolman, Y. (2014). Beating the blues: Is there any music in fighting cyanobacteria with ultrasound? Water Research, 66, 361-373.

Maraşlığlu, F., (2007). An investigation on the phytoplankton of Yedikır Dam Lake (Amasya-Turkey) and it's seasonal variation (in Turkish with English abstract). Ondokuz Mayıs Unıversity The Institute of Science, PhD Thesis, Samsun.

OECD (1982). Eutrophication of waters. monitoring, assessment and control. Paris: Organisation for Economic Co-Operation and Development, $154 \mathrm{pp}$.

Özbay, Ö., Göksu, M.Z.L., \& Alp, M.T. (2011). Bir akarsu ortamında (Berdan Çayı, Tarsus-Mersin) en düşük ve en yüksek akım dönemlerinde bazı fizikokimyasal parametrelerin incelenmesi. Fırat Üniversitesi Fen Bilimleri Dergisi, 23 (1), 31-39.

Ryding, S.O., \& Rast, W. (1989). The control of eutrophication of lakes and reservoirs (Manual The Biosphere Series 1). The Parthenon Publishing Group, New Jersey.

Schindler, D.W., Hecky, R.E., Findlay, D.L., Stainton, M.P., Parker, B.R., Paterson, M.J., Beaty, K.G., Lyng, M., \& Kasian, S.E.M. (2008). Eutrophication of lakes cannot be controlled by reducing nitrogen input: Results of a 37-year whole-ecosystem experiment. Proceedings of the National Academy of Sciences of the United States of America, 105, 11254-11258.

Schindler, D.W. (2012). The dilemma of controlling cultural eutrophication of lakes. Proceedings of the Royal Society B-Biological Sciences, 279, 4322-4333.

Sömek, H., \& Ustaoğlu, M.R. (2016). Yaz aylarında Batı Anadolu'nun bazı dağ göllerinin (Denizli-Muğla) fitoplankton kompozisyonu ve trofik durum indeksi değerleri. Ege Journal of Fisheries and Aquatic Sciences, 33(2), 121-128.

Şen, B., \& Koçer, M.A.T. (2003). Su kalitesi izleme. XII. Ulusal Su Ürünleri Sempozyumu, 2-5 Eylül 2003, Elazı̆g. pp.567-572.

Tanyolaç, J. (2000). Limnoloji ders kitabı. Hatiboğlu Yayıncılık, Ankara, 294 s. 
Taş, B. (2003). An investigation on the phytoplankton and it's seasonal variation of Derbent reservoir (Bafra, Samsun-Türkiye) (in Turkish with English abstract). Ondokuz Mayıs Unıversity The Institute of Science, PhD Thesis, Samsun.

Taş, B., Tepe, Y., Ustaoğlu, F., \& Alptekin, S. (2019). Benthic algal diversity and water quality evaluation by biological approach of Turnasuyu Creek, NE Turkey. Desalination and Water Treatment, 155, 402-415.

Tepe, R., Karakaya, G., Şahin, A.G., Sesli, A., Küçükyılmaz, M., \& Aksağan, A. (2018). Karkamış Baraj Gölü trofik durumu. International Journal of Innovative Engineering Applications, 2(1), 1-3.

Wetzel, R.G. (2001). Limnology. Lake and River Ecosystems. $3^{\text {rd }}$. Ed. Academic Press, San Diego.

Varol, M. (2013). Batman Baraj Gölü'nün trofik durumunun belirlenmesi, Anadolu Doğa Bilimleri Dergisi, 4(2), 51-59.

Yağcı, M.A., Alp, A., Akın, Ş., Yağcı, A., Bilgin, F., Atay, R., Dölcü, B., Uysal, R., Cesur, M., Bostan, H., \& Yeğen, V. (2013). Eğirdir Gölü’ne atılan gümüş balığının (Atherina boyeri Risso, 1810) besin zincirindeki etkileri. Tagem Haysüd Projesi, Isparta, $332 \mathrm{~s}$.

Zeybek, M., Kalyoncu, H., \& Ertan, Ö.O. (2012). Eğirdir ve Kovada göllerini bağlayan Kovada Kanalı ile göllerin kanala yakın bölümünde trofik durumun belirlenmesi, Ege Journal Fish Aquatic Sciences, 29(3), 137-141. 